\title{
Reflexões poéticas sobre educação
}

\section{Poetic reflections on education}

\author{
Reflexiones poéticas sobre la educación
}

Fausto dos Santos Amaral Filho ${ }^{1}$

\author{
Vazio \\ Tem um vazio que fica \\ Uma angústia \\ Ao final do curso \\ Se por profissão \\ Montasse carros \\ - como seria do gosto do Senhor Reitor - \\ Não haveria problemas \\ Que eles \\ Das fábricas \\ Saem prontos e acabados \\ Com os parafusos \\ Todos apertados \\ Aqueles com defeito \\ Recall \\ Com os que saem \\ Da minha linha de montagem \\ Mal tenho tempo \\ De lhes dizer adeus
}

Que se cuidem!

$$
\begin{gathered}
\text { Pois o trânsito } \\
\text { É perigoso }
\end{gathered}
$$

1 Programa de Pós-Graduação em Educação, Universidade Tuiuti do Paraná. Rua Sydnei Rangel Santos, 238, Santo Inácio. Curitiba, PR, Brasil. 82.010-330. fausto.santos@utp.br 


\title{
Réquiem
}

Quem trabalha

Quer condições de trabalho
A ferramenta
$\mathrm{O}$ instrumento
O salário

Quando alguém cria um problema

Não significa que haja problema

Todos se mexem

Para todos os lados

Todos caminham

Aos esbarrões

Para lugar nenhum

Cuspidos

Todos saem formados

Com suas becas de filó

Exemplares vulgares

De um saber decadente

Já se foi a época das Universidades

Restou apenas

A ilusão de um saber fragmentado

E o tilintar opaco das moedas

\section{Pseudo}

\author{
A pseudo-intelectua \\ De esquerda \\ Gostava \\ De dizer: \\ "Nada me sabe \\ Melhor \\ A não ser \\ Eu mesma" \\ Soberba
}




\title{
Professora
}

$A i$, ai

Professora querida

Sala de aula

Power point

Maquinaria

Gráficos

Tabelas

Esquemas

Ai, ai

Professora querida

Como será

Que seria

Se

Ao invés

De tanta metodologia

A sua aula tivesse

Um pouco

Um pouquinho mais

De melodia...

\section{Academia}

\author{
A Academia \\ É douta \\ Por demais \\ Impressionada \\ Pelo seu próprio saber \\ Onanisticamente \\ Produz fantasias \\ Simulacros verdadeiros \\ Da sua própria vaidade. \\ A Academia \\ É operosa \\ Ciosa \\ Dos seus compromissos \\ Quer um país melhor \\ Muito mais bonito \\ Por isso pensa \\ Pensa, pensa, pensa, \\ Pensa em demasia.
}




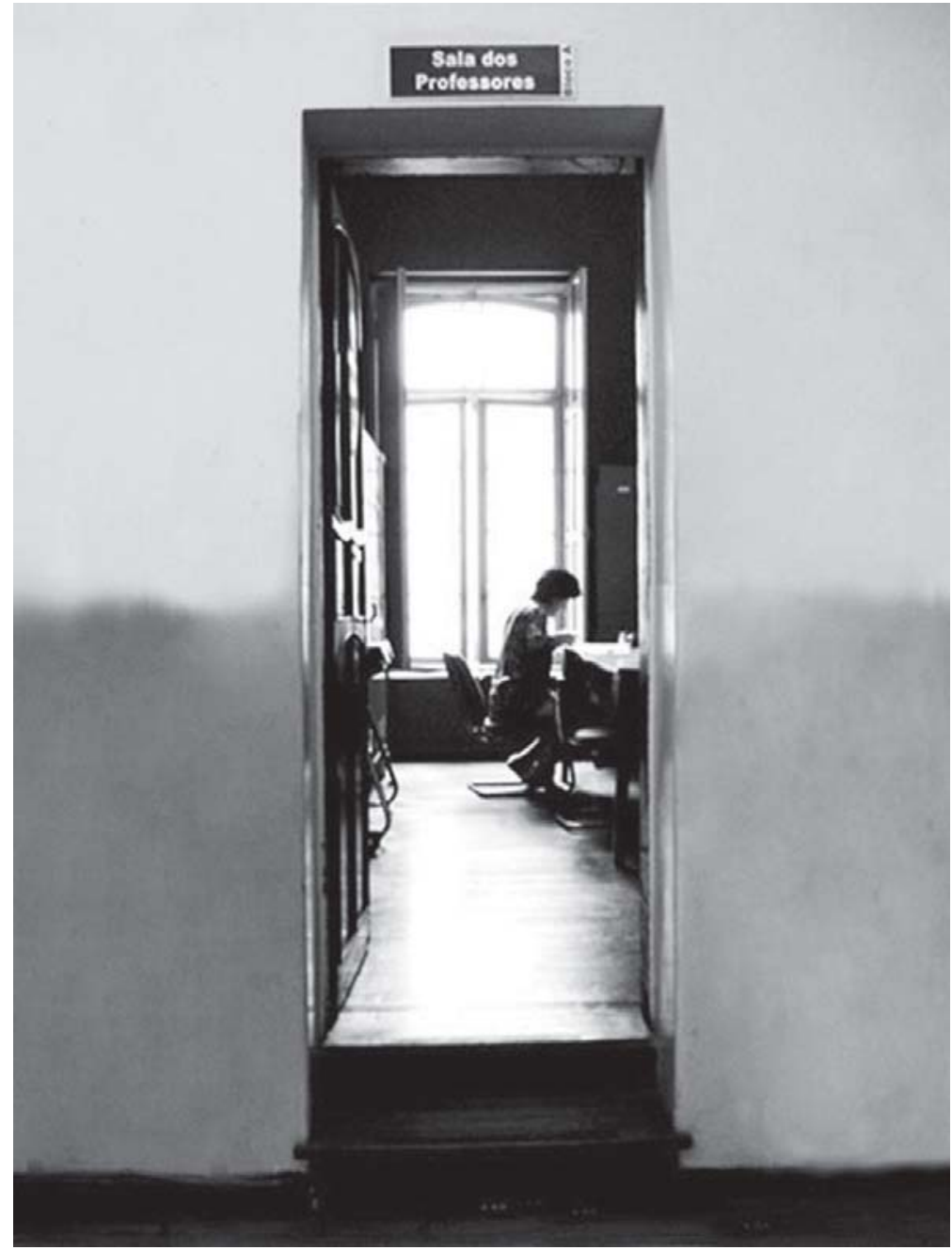

Ricardo Pozzo, Projeto Urbe fágica, s/d 